\title{
Exploring biology teachers' pedagogical content knowledge in the teaching of genetics in Swaziland science classrooms
}

\author{
Eunice Mthethwa-Kunenea, Gilbert Oke Onwub \& Rian de Villiersb
}

a National Curriculum Centre, Manzini, Swaziland

b Department of Science Mathematics and Technology Education, Faculty of Education, University of Pretoria, Pretoria, South Africa

\begin{abstract}
This study explored the pedagogical content knowledge (PCK) and its development of four experienced biology teachers in the context of teaching school genetics. Pedagogical content knowledge was defined in terms of teacher content knowledge, pedagogical knowledge and knowledge of students' preconceptions and learning difficulties. Data sources of teacher knowledge base included teacher constructed concept maps, pre- and post-lesson teacher interviews, videorecorded genetics lessons, post-lesson teacher questionnaire and document analysis of teacher's reflective journals and students' work samples. The results showed that the teachers' individual PCK profiles consisted predominantly of declarative and procedural content knowledge in teaching basic genetics concepts. Conditional knowledge, which is a type of meta-knowledge for blending together declarative and procedural knowledge, was also demonstrated by some teachers. Further, the teachers used topic-specific instructional strategies such as context based teaching, illustrations, peer teaching, and analogies in diverse forms but failed to use physical models and individual or group student experimental activities to assist students' internalization of the concepts. The finding that all four teachers lacked knowledge of students' genetics-related preconceptions was equally significant. Formal university education, school context, journal reflection and professional development programmes were considered as contributing to the teachers' continuing PCK development. Implications of the findings for biology teacher education are briefly discussed.
\end{abstract}

Keywords: Pedagogical content knowledge (PCK), school genetics, biology teacher, PCK development

\section{Introduction}

A major concern in science teacher education is the development of teachers' knowledge base for improving classroom practice and students' learning (Brown, Friedrichsen \& Abell, 2013; Kind, 2009). According to De Jong, Veal and Van Driel (2002), this concern has come about, first, as a result of studies that show a strong relationship between what teachers know (content knowledge), and how they teach (pedagogical knowledge). And secondly, constructivist views on science teaching and learning suggest that teachers' knowledge base must of necessity include knowledge of students' preconceptions or alternative frameworks which could be used as the basis of a good teaching point on students' behalf. The three types of teacher knowledge, namely, subject matter content knowledge, pedagogical knowledge, and knowledge of students' preconceptions and learning difficulties, relate to what Shulman (1986) and others (Loughran, Berry \& Mulhall, 2012) have collectively referred to as pedagogical content knowledge (PCK). Pedagogical content knowledge has been simply described as that teacher knowledge which allows teachers to assist students to access specific content knowledge in a meaningful way (Miller, 2007).

Recent global trends in science education enrolment show that not many students opt for science at secondary school level. In addition, there is also widespread poor performance and negative attitudes towards the subject matter itself (Barmby, Kind \& Jones, 2008; Kazeni \& Onwu, 2013). In Swaziland, where the study reported here was undertaken, a recent World Bank Report on the status of secondary education noted that overall, Swazi students perform poorly in mathematics and science subjects in 
public examinations (Marope, 2010). The Report identified teacher competence or lack of it as a veritable source of students' poor performance in the sciences. In support, the Examination Council of Swaziland (ECOS) examination results over the years have shown that on average less than one third of the candidates (29\%) who sit the biology examinations qualify for biology-related programmes at tertiary level (ECOS, 2007-2012). Additionally, the country's chief examiners' biology performance reports highlight the fact that school genetics is one area in which candidates have consistently performed abysmally over the years (ECOS, 2008, 2009, 2012). Genetics is a topic that research has shown students tend to struggle with worldwide (Chu \& Reid, 2012).

Despite the poor performance in science public examinations, there are isolated pockets of schools with successful teachers throughout Swaziland who engage their students in effective learning and thus consistently produce good results in the public examinations. This study's interest was with the successful teachers who teach biology in such schools. Little is known about how they do so: what critical knowledge and skills they have and the experiences that motivate and sustain their practice. The assumption here is that successful teachers would be expected to have developed 'rich PCK' base in biology topics such as genetics which enables them to teach in ways that enhance students' achievement (Loughran et al., 2012). In this study the term 'successful teachers' refers to biology teachers who have consistently produced a minimum $70 \%$ credit passes (Grades $\mathrm{C}$ and above) in the Swaziland school leaving certificate biology examinations for five years (2007-2012) since the introduction of the new science curriculum. Grade $\mathrm{C}$ is the minimum symbol for entry into sciencerelated degree programmes at university level in Swaziland.

\section{Conceptualization of pedagogical content knowledge}

Although not previously considered among the traditional frameworks for research in education, in recent times however PCK offers a new perspective for science education research within teacher education .The notion of pedagogical content knowledge was first introduced by Shulman as a form of knowledge that connects a "teacher's cognitive understanding of subject matter content and the relationships between such understanding and the instruction teachers provide for students" (Shulman, 1986:25). In its original context, PCK represents that particular amalgam of content and pedagogy that is uniquely the province of teachers and distinguishes a teacher from a subject matter specialist (Shulman, 1986).., According to Shulman, PCK results from the blending of content knowledge with pedagogical methods. Through that combination of knowledge, teachers gain a perspective that enhances their abilities to present specific topics in a specific subject area (Miller, 2007).

In Shulman's conceptualization, PCK in science teaching for instance consists of representations of subject matter, which could be analogies, illustrations, examples, explanations, and demonstrations aimed at making it comprehensible for students (Shulman, 1986). It also includes an understanding of what makes the learning of particular topics easy or difficult, which might be the preconceptions that students of different backgrounds bring with them to the classroom. These two elements are said to be intrinsically linked, in the sense that the more a teacher is able to discern students' preconceptions and learning difficulties regarding a specific topic the better the chances of developing effective strategies to teach the topic (cf. Van Driel, De Jong, \&Verloop 2002)

Continuing research in this area of teacher knowledge have led other researchers (Grossman, 1990; Juttner, Boone, Park \& Neuhaus, 2013; Juttner \& Neuhaus, 2012; Magnusson, Krajcik \& Borko, 2001) to elaborate on Shulman's model by proposing that teachers develop or construct PCK not only by the amalgam of content and pedagogy but also by blending those two knowledge categories with student, curricular and context knowledge. For example, in addition to content knowledge, curricular and pedagogical knowledge, Grossman (1990) has included knowledge of context as the specific knowledge that is unique to the learning setting. 
Criticizing Shulman's view of PCK as static, Cochran, deRuiter \& King, (1993) took a constructivist perspective of PCK, arguing that the word 'knowledge' in PCK was too rigid for the constructivist perspective. It inferred a stagnant notion of constructed PCK that did not change. They proposed the term 'pedagogical content knowing' to imply that PCK was a versatile form of knowledge that required continual change in order to meet the needs of students. Similarly, Carlsen (2001) contended that PCK should not be thought of as a fixed body of knowledge rather its dynamic nature should be emphasized. This changeable nature of PCK however is somewhat problematic in the sense that it makes it difficult to identify specific constructs of this category of knowledge (Miller 2007). In addition it could lead to an exaggerated notion of PCK that is beyond its meaning and boundaries Others however (e.g. Appleton, 2006) have maintained that by including in PCK teacher knowledge of students and their preconceptions, Shulman's conception has elements of a student-centred pedagogy that is constructivist in orientation.

Given these various perspectives with regard to PCK what can be deduced is that first, effective teaching is linked to the quality of teachers' PCK. Secondly, the discourse also highlights the nebulous and tacit nature of PCK. Teachers as learners construct their own knowledge and as such differences in PCK constructs between teachers are likely to exist. These differences in PCK constructs have been comprehensively reviewed and summarized for instance in the context of biology teaching in recent publications (Schmelzing, Van Driel, Juttner, Brandenbusch, Sandmann \& Neuhaus (2013). The reviews indicate that there is no universally accepted conception of what constitutes PCK. Despite the lack of consensus in the definition of PCK however, most science education researchers have embraced Shulman's conception (Abell, 2007; Kaya, 2009), notably that of the blending of content and pedagogy into an understanding that allows the subject matter teacher to more thoroughly understand how to present a topic in an accessible way. Researchers have used the definition as a basis for their conceptualizations, depending on their research questions (Juttner et al., 2013; Lee \& Luft, 2008).

According to Lee and Luft (2008) all the perspectives of PCK can be classified as integrative or transformative. From an integrative viewpoint, PCK is seen as a mixture of types or categories of knowledge that tend to exist as separate units. This perspective therefore allows researchers to focus on specific questions regarding those separate units of knowledge and on appropriate methodology for answering those questions (Miller 2007). As an amalgam of knowledge categories, each of the constituent domains can be measured separately, and this is the sense in which PCK is conceptualized in this study. PCK therefore can be considered a useful theoretical framework, for organizing and collecting data on teacher knowledge base. In this study, PCK is construed as the blending of topicspecific content knowledge, pedagogical knowledge and knowledge of students' preconceptions and learning difficulties. They are the key elements that are intrinsically linked in ways that help the teacher make the content accessible to students. Further, the notion of amalgam, implies that each of those knowledge categories can exist separately or as a unit to constitute PCK. During teaching for instance, the teacher integrates knowledge of all the various domains individually to create efficacious learning opportunities (Rollnick et al, 2008) and their ability to do so, to integrate the components is determined by their knowledge of the individual components.

\section{Purpose of Study}

The purpose of this study was to investigate the PCK profile of experienced successful biology teachers and how they developed it (PCK) in the context of teaching basic school genetics concepts.

The literature shows that PCK research in biology education is rare (Kind, 2009) and many of the related studies carried out have focused on pre-service teachers and few have been on experienced teachers, particularly those that "reveal some teaching examples of teachers with rich PCK" (Ekis, 2012 , p. 12). Hence this study's interest was with specific questions about experienced in-service biology teachers' PCK profiles and how they developed it in the context of teaching basic school genetics concepts. 
The study attempted to address the following research questions:

1. What genetics content knowledge do the identified biology teachers have and demonstrate in teaching genetics concepts?

2. What topic-specific instructional strategies do these teachers use in teaching school genetics?

3. What knowledge of students' preconceptions and learning difficulties, if any, do these teachers have and demonstrate during genetics lessons' planning and implementation?

4. How did these teachers develop their PCK in genetics teaching?

\section{Context}

The topic of genetics features in the Swaziland General Certificate of Education (SGCSE) biology syllabus only in Grades 11-12 (the last two grades of secondary education level). Students are expected to grasp the basic concepts in genetics such as chromosome, gene and cell division (mitosis and meiosis) which form the foundation for understanding the more complex genetics concepts. The concern of the study was with the basic genetics concepts and successful biology teachers' pedagogical content knowledge structures in teaching them.

\section{Theoretical approach and central concepts}

In this study, as we indicated earlier PCK was used as a theoretical framework, consisting of teacher content (school genetics) knowledge, pedagogical knowledge (knowledge of instructional strategies), and knowledge of students' preconceptions and learning difficulties to explore the main research questions. This approach is consistent with the views of Gess-Newsome (2001, p. 10) who had earlier suggested that PCK provides "... a new analytical frame for organizing and collecting data on teacher cognition". Miller (2007) later concurred by suggesting that PCK as a theoretical framework offers science education researchers with a new perspective for collecting and analyzing data about teacher knowledge or cognition.

In using PCK as a theoretical framework the following assumptions were made (Miller 2007): that PCK is a type of teacher knowledge that underpins the knowledge of an expert teacher; PCK can be used as a framework to describe the origin of this critical teacher knowledge; and that PCK is a continually changing body of knowledge implying a constructivist process. It was also assumed that instruments can be devised to identify and measure the various domains of PCK as operationally defined in the study. To this end, the literature on the measurement of the different PCK components is briefly reviewed to justify the methodology used in addressing the four research questions.

\section{Teacher content knowledge}

Assessing teacher content knowledge in relation to PCK poses a number of challenges (McConnell, Parker \& Eberhardt, 2013) and past studies have used varied methodologies such as convergent and inferential techniques, visualisation techniques and multiple-method evaluation to identify aspects of PCK (Miller 2007). Convergent and inferential methods have been criticized for several reasons. Firstly, these methods involve the use of multiple choice and short answer close-ended tests designed to measure teacher knowledge, and therefore assume the existence of a correct answer which is inconsistent with the concept of PCK. More recently, investigators (Ijeh \& Onwu, 2013; Kapyla, Heikkinen \& Asunta, 2009; Rollnick, Bennett, Rhemtula, Dharsey \& Ndlovu, 2008) have used interviews and lesson observations to study content knowledge. McConnell et al. (2013) in their review asserted that interviews and observations provide deep understanding of content knowledge, but are time consuming. Despite the time consuming nature of such instruments researchers have continued to successfully use interviews and lesson observations to assess science and mathematics teachers' content knowledge (Ijeh \& Onwu 2013; Rollnick et al 2008). Rollnick et al. (2008) for instance, used content representations (CoRes) to capture and portray the participating chemistry 
teachers' subject matter knowledge and PCK by asking them to state and describe the big ideas and/or key concepts to be taught regarding the mole. In addition to the use of interviews, lesson plans, questionnaire and observations, other researchers (e.g. Greene, Lubin, Slater \& Walden, 2013) have used concept maps as tangible representations to demonstrate teachers' content knowledge structure, in terms of their gains and acquisition

In this study, teachers' genetics content knowledge was measured using multiple sources of data collection, namely, interviews, lesson plan, and lesson observation schedules primarily for triangulation of data. Concept mapping was also used to assess teacher content knowledge as an additional supplementary evaluation instrument that is respectful of the teachers as professionals. Teachers are normally reluctant to take any content knowledge tests.

For the purpose of this study we conceptualised PCK biology content knowledge in terms of three knowledge dimensions of declarative, procedural and conditional knowledge as described by Juttner et al. (2013). Declarative or propositional knowledge designates, 'knowing it', which is required for stating or explaining facts or concepts. Procedural knowledge indicates 'knowing how', which in biology involves knowledge about how biological processes work and/or the procedures for doing something. The third category, conditional knowledge, is about knowing "the how and why". Thus in biology teaching, content knowledge is not only "to know or understand that something is so; the teacher must further understand why it is so" (Shulman 1986, p. 9). This knowledge taxonomy proposed by Juttner et al. (2013) was used to analyse the lesson observation protocols for evaluating the participating teachers' content knowledge.

\section{Teacher pedagogical knowledge}

Kapyla et al. (2009) used lesson plans, questionnaires and interviews to assess biology student teachers' pedagogical knowledge component of PCK. In their study, pre-service teachers were asked to explain their lesson plans in an attempt to identify their PCK with respect to what they know about planning, and classroom implementation. The methodology used in studies of this nature was limited, in that it did not include observing how the teachers used that knowledge in classroom practice. Other studies (Park \& Chen, 2012; Rollnick et al., 2008) have avoided this shortcoming by conducting classroom observation. For the study reported here, we used a variety of data collection instruments of teacher interviews, lesson observation schedule, teacher questionnaire and document analysis to identify teachers' pedagogical knowledge of genetics teaching using a time schedule which involved (i) the conducting of pre-lesson interviews and analysis of lesson plan (pre-lesson planning); (ii) within lesson observation (during teaching) and post-lesson interview and questionnaire (postteaching reflection).

\section{Teacher knowledge of students' preconceptions and learning difficulties}

Various studies (De Jong, 2010; Henze, Van Driel \& Verloop, 2008; Morrison \& Lederman, 2003; Penso, 2002) have assessed science teachers' knowledge of students' preconceptions and learning difficulties in the context of PCK identification. Henze et al (2008) used only interview sessions. Morrison and Lederman (2003) used multiple sources of data including in-depth lesson observation; pre-and post-lesson interviews, analysis of science teachers' lesson plans; and analysis of students' written work to assess teachers' knowledge of students' preconceptions. Our study examined the biology teachers' knowledge of students' preconceptions and learning difficulties in genetics teaching using teacher lesson plans, interviews and lesson observations for triangulation and validity of findings. 
Pedagogical content knowledge development has been investigated in at least two ways. One way is through longitudinal studies in which the growth or gain in teachers' knowledge is traced over time (Arzi \& White, 2008; Brown et al., 2013; Henze et al., 2008). The other approach is by finding out from the teachers themselves through interviews about how they think they might have acquired their existing knowledge of teaching particular topics and what contributed to their growth (Drechsler \& Van Driel, 2008; Ijeh \& Onwu, 2013). The latter approach was considered a convenient and workable option and so teacher interview questions were crafted based on factors that research suggests were likely to impact on PCK development: reflection, research, disciplinary courses, classroom experience, and continuing professional development.

\section{Method}

The study used a qualitative research approach within an interpretive paradigm involving multiplecase study method (Merriam, 2009) to explore the research questions. Despite the inherent constraints of the case study method such as the lack of generalizability of findings, our interest was with providing a rich and detailed description of the case, the individual biology teacher's PCK profile and how it is said to develop.

\section{Participants}

The participants were four Grades 11-12 biology teachers, three females and one male, teaching in different fairly-resourced Swaziland secondary schools. They are referred to by pseudonyms as Lucy, Lily, Lillian and Leon. The teachers were purposively selected firstly, based on their schools' performance in biology public examinations, and followed by the recommendations of the relevant school science inspectors and school principals. The four teachers graduated from the same university in Swaziland and earned Bachelor of Science degrees and majored in biology. They also had post graduate teaching certificates and/or diploma in biology education. Their years of teaching experience in Grades 11-12 biology ranged from 5-22 years (Lillian-5, Lucy-10, Lily-17 and Leon-22). Class sizes they respectively taught ranged from 25-49 students (Lillian-49; Lucy-27; Lily 29; Leon-25). Interestingly enough the most experienced teacher had the smallest class size while the least experienced had the largest.

\section{Data collection}

Data collection instruments were developed to address each of the research questions and individually administered to the four teachers in their school setting. Table 1 displays the instruments used to address each of the research questions. Each teacher was required to keep a reflective journal with stated guidelines for completing it over the four week period of teaching the genetics topic.

\section{Concept mapping}

The concept mapping exercise required the participating teachers, first, to list concepts they considered key in the school genetics topic of Inheritance for Grades 11-12; second, to arrange the concepts in a linear hierarchical format showing the sequence in which they would 'logically' teach them(starting with the concept to be taught first and ending with the last) to Grade 11 students; and lastly, to represent in a graphically hierarchical fashion the relationship between the listed key concepts indicated by a connecting line with linking words or phrases where appropriate to specify the relationship. 
Table 1: Research instruments used to address the research questions $\mathrm{m}$

\begin{tabular}{|c|c|}
\hline Research question & Research instruments \\
\hline \multirow{3}{*}{$\begin{array}{l}\text { What genetics content knowledge do } \\
\text { the biology teachers have and } \\
\text { demonstrate in teaching genetics } \\
\text { concepts? }\end{array}$} & $\begin{array}{l}\text { Teacher concept map of biology curriculum } \\
\text { genetics topics for grades } 11 \text { and } 12\end{array}$ \\
\hline & $\begin{array}{l}\text { Teacher pre-lesson interview schedule about } \\
\text { their genetics topic lesson plan }\end{array}$ \\
\hline & $\begin{array}{l}\text { Lesson observation schedule for analysing } \\
\text { within-lesson genetics topic teaching }\end{array}$ \\
\hline \multirow{4}{*}{$\begin{array}{l}\text { What topic-specific instructional } \\
\text { strategies do these teachers use in } \\
\text { teaching school genetics? }\end{array}$} & $\begin{array}{l}\text { Teacher pre-lesson interview schedule on their } \\
\text { genetics topic lesson plan }\end{array}$ \\
\hline & $\begin{array}{l}\text { Lesson observation schedule on classroom } \\
\text { practice }\end{array}$ \\
\hline & $\begin{array}{l}\text { Post-teaching teacher questionnaire on observed } \\
\text { genetics lessons }\end{array}$ \\
\hline & $\begin{array}{l}\text { Document analysis - Lesson plan, samples of } \\
\text { students' work book. }\end{array}$ \\
\hline \multirow{4}{*}{$\begin{array}{l}\text { What knowledge of students' } \\
\text { preconceptions and learning } \\
\text { difficulties, if any, do these teachers } \\
\text { have and demonstrate during lesson } \\
\text { planning and implementation? }\end{array}$} & $\begin{array}{l}\text { Teacher pre-lesson interview schedules about } \\
\text { their genetics topic lesson plan }\end{array}$ \\
\hline & $\begin{array}{l}\text { Lesson observation schedule for analysing } \\
\text { within lesson teaching }\end{array}$ \\
\hline & $\begin{array}{l}\text { Post-teaching teacher questionnaire on observed } \\
\text { genetics lessons } \\
\text { Teacher post-lesson interview about usual areas } \\
\text { of learners' difficulty if any }\end{array}$ \\
\hline & $\begin{array}{l}\text { Document analysis - Lesson plan, samples of } \\
\text { students' work book }\end{array}$ \\
\hline \multirow[t]{2}{*}{$\begin{array}{l}\text { How do these teachers develop their } \\
\text { PCK in genetics teaching? }\end{array}$} & $\begin{array}{l}\text { Teacher post-lesson interview schedule about } \\
\text { teachers' educational background and } \\
\text { professional work experiences }\end{array}$ \\
\hline & $\begin{array}{l}\text { Document analysis - Teacher reflective journals } \\
\text { Curriculum documents and students' workbook }\end{array}$ \\
\hline
\end{tabular}




\section{Pre-lesson interviews}

A semi-structured pre-lesson interview schedule was used to gain insight into the teachers' genetics content knowledge, instructional strategies and knowledge of students' preconceptions and learning difficulties. Specific prompts from Content Representations (CoRes), a tool developed for capturing and portraying science teachers' PCK (Loughran et al., 2012) were used to probe the teachers' lesson plan descriptions and these concerned, the concept (s) or big ideas to be taught in the lesson; what they intended students to know about the concepts; the reasons why those are important; anything else they know about the concepts, which they did not intend their students to know yet; the teaching strategies they were going to use and particular reasons for using them; and students'preconceptions and learning difficulties if any, they might have taken into account in planning the lesson. All interviews were audio-recorded and transcribed verbatim and validated by the participants through member checking.

\section{Lesson observations}

A lesson observation schedule was used to assess the biology teachers' content knowledge, knowledge of instructional strategies and knowledge of students' preconceptions and learning difficulties. It focused on the observed genetics content that was taught, the teaching approaches as well as teacher-leaner interactions. Attention was also paid to the prior knowledge the teachers had of their students' preconceptions if any, and the strategies they used to solicit or identify students' preconceptions and learning difficulties. Students' comments including the clarifications they asked for, their requests for more explanations, and their answers to their tasks were noted. Data from the observation schedule were categorized into the three PCK components utilized in the study. Specifically, teacher content knowledge was obtained through analysis of lesson protocols and further classified into declarative, procedural and conditional content knowledge; pedagogical knowledge through the lesson objectives and instructional strategies used and lastly knowledge of students' preconceptions and difficulties through lesson plan, teacher questioning and assessment techniques and student feedback. Although a minimum of six lessons were video-taped for each teacher, two lessons in which all four teachers individually dealt with the same 'Inheritance' topic were selected for the purpose of this paper.

\section{Post-lesson teacher questionnaire}

The questionnaire was about the instructional strategies the teachers used during the observed lessons: what informed the teachers' choice of instructional strategies during the lesson, and the changes if any they would likely make the next time they taught the same concepts. It also focused on teacher knowledge of students' preconceptions and the learning difficulties. They were also asked to indicate how they gained knowledge of their students' preconceptions and learning difficulties if any, and what they thought were the sources, and how they addressed such difficulties, if at all.

\section{Post-lesson teacher interviews}

Post-lesson teacher interviews were conducted for the purpose of finding out what the teachers thought could have contributed to the development of their PCK-the three knowledge domains that were investigated. To this end they were asked questions on the basis of factors research suggested could influence their PCK such as the courses that they had studied during university education, and how they thought those impacted on their classroom teaching experiences etc.

\section{Document analysis}

Document analysis involved examination of teachers' lesson plans, students' work book and journal reflective notes on aspects of subject matter content, instructional strategies and any evidence of knowledge of students' preconceptions and learning difficulties. For instance, examination of lesson 
plans gave indication of whether the teachers had any knowledge of students' preconceptions and learning difficulties and whether they took that knowledge into account as a possible teaching point on the students' behalf. The teacher's reflective journal included guidelines for the teacher to reflect on their lesson experiences and to document their successes, difficulties and failures with reasons and explanations for future improvement. The document analysis was essentially for triangulation of data from sampling of learner work books to looking for consistency in what was said and what was done.

All the instruments for the main study were content validated by three qualified and experienced biology university lecturers and pilot tested with three non-participating biology teachers.

\section{Data analysis}

\section{Scoring of concept mapping}

A quantitative method (Greene et al., 2013) was used to score the teachers' concept maps. A developed rubric allocated marks, first, to the number of correct key concepts (nodes) that were listed; and second, to the number of concepts that were hierarchically (correctly) arranged (links). The rubric deducted marks for incorrect arrangement of concepts. The Swaziland General Certificate of Secondary Education (SGCSE) biology syllabus for Grades 11-12 (Examination Council of Swaziland 2009:2) was used for assessing teachers' concept maps in terms of key genetics topics listed, the hierarchical order or sequence in which they were arranged for teaching and the linkage or relationship among them. The rubric allocated 20 marks for all concepts correctly listed (1 mark for each correct concept).

For the sequencing of topics, the rubric allocated marks to the number of topics that were correctly arranged in a hierarchical manner. This question was allocated 10 marks. For the relationships among the genetics concepts, specifically those relevant to grade 11 , the rubric allocated one mark for correctly indicating each of these connections: chromosome-gene; chromosome-mitosis; chromosome-meiosis; gene-mitosis; gene-meiosis; gene-monohybrid inheritance; meiosismonohybrid inheritance; chromosome (gene)-variation; gene-selection; gene-genetic engineering. The mark allocation for this question was 10 marks.

A total of 40 marks was scored for the concept mapping exercise. Percentages of teachers' scores were calculated.The analysis of data from other sources involved the transcribing of audio-recorded pre and post lesson interviews and video-taped lessons. The classroom observation analysis involved an iterative coding and categorisation of teachers' narratives, lesson activities and interactions designed to identify themes and gaps with reference to the three components of PCK as defined. A detailed example of the lesson observation analysis is included as an Appendix. The teachers' responses to questionnaires, journal reflective notes, and notes from reviews of students' workbook were cross-checked with the respondents and subsequently analysed for triangulation.

\section{Results}

The results are presented in an attempt to address each of the four research questions.

\section{Teachers' demonstrated genetics content knowledge in teaching genetics concepts}

Analysis of the teachers' concept maps indicated that Lucy scored 95\%, Leon 90\%, Lillian $90 \%$ and Lily $85 \%$. All four teachers scored $85 \%$ and above and were considered to possess adequate genetics curriculum content knowledge to teach at that grade level.

In the pre-lesson individual interviews, the teachers clearly stated the key genetics concepts they were going to teach on the topic of Inheritance, and what they intended their students to know about them. Lucy, Lily Leon and Lillian indicated that they had planned first to teach the concepts of inheritance, 
chromosomes, genes, alleles, diploid and haploid nuclei in that order. They intended their students to know the definitions of these genetics terms, their basic structures and differences. Thereafter, they would teach the concepts of mitosis and meiosis focusing on answering the What? The Why? and How? about those two biological processes. Lucy and Lillian added that they would omit details of the stages such as "the idea of crossing over of chromosomes during the process of meiosis which brings about variation". Leon did not intend his students to know how the processes of cell division occur, and so had not planned on teaching the stages of mitosis and meiosis. His reason being that, the 'details of stages are not required' (ECOS, 2009, p. 21) in the syllabus. None of the four teachers expected their students to master the names of the stages of mitosis and meiosis but all of them however insisted that they intended their students to know the conceptual differences between mitosis and meiosis -and why the processes are necessary in an organism. using a blend of their conditional knowledge.

Explanations were given by each of the teachers why the teaching of genetics at that level was important; not only because it is included in the biology syllabus but also because of its scientific merit. According to Lily for instance, the "big scientific ideas connected to genetics" would enable students to make sense of "human development, cell growth, including the characteristics and conditions of inheritance" and also as a "basis for further studies in biology". Their other responses revealed that they knew more content than they were required to teach in high school biology. To illustrate, Lucy and Lillian indicated that they could extend the topic by "teaching crossing over of chromosomes during meiosis". Leon talked about "the stages of mitosis and meiosis, and di-hybrid inheritance crosses as part of my knowledge of genetics that would fit into the topic at a higher level". Lily referred to "the synthesis of proteins"

The recommended biology textbooks and curriculum teaching guides were the four teachers' main sources of information. They all began their lessons by first reviewing previously taught but related concepts of cell structure in order to locate the hereditary structures in the nucleus. This review was followed by the teacher providing correct definitions and basic descriptions and functions of the particular concepts, namely chromosomes, genes and alleles in line with the biology syllabus. The emphasis here was on their use of declarative knowledge to transmit information particularly with regard to the definitions of the new concepts and to review previously taught related concepts Lucy defined a chromosome as "a thread-like structure of DNA, made up of genes found in the nucleus" and genes as "chemical structures made up of DNA found on chromosomes and they control particular characteristics ... a section of DNA which carries genetic information about a particular characteristic or protein".. She linked those concepts of gene and chromosome to previous work on cell structure and gamete fertilization. She subsequently followed this up by explaining the relationships and differences among the various concepts, of chromosome and gene; gene and allele using schematic diagrams on the blackboard and the physical models made by the students themselves as teaching points. Lily, Leon and Lilian in their teaching, behaved likewise, starting with whole class review of previously taught related concepts of cell structure and fertilization and followed by factual description of the basic hereditary structures and functions of chromosomes, genes and alleles using their declarative knowledge. Lily for instance defined "Chromosomes are structures found in the nucleus that carry the genes ... made of DNA". On a chromosome there are several genes. A gene carries specific information about a particular characteristic of an organism". She followed this up with the definitions of the other concepts namely genes and alleles and later using factual information carefully highlighted the relationship and differences between them. In teaching those concepts all four teachers used mainly declarative knowledge, for stating facts and explaining differences or relationships if any, between concepts. For the teachers once their lessons had dealt with the basic 
hereditary structures and functions they logically proceeded to subsequent lessons on the processes of mitosis and meiosis.

In the teaching of mitosis and meiosis, Lucy provided step by step descriptions of the processes of their formation and the differences between them together with clear explanations of why both are regarded as important processes in the development of the organism, notably for "cell growth, replacement of worn-out cells and sexual reproduction". The emphasis here was in the use of procedural and conditional content knowledge. By describing both the 'why' of the processes of mitosis and meiosis, and the 'how' of their stages, Lucy like her other counterparts in effect was demonstrating the presence of a blend of both procedural and conditional knowledge (Juttner et al 2013) within her PCK competence repertoire. Indeed her PCK content knowledge domain could be construed as reflecting the three knowledge areas of declarative, procedural and conditional knowledge...........

Lily as well used primarily her declarative, procedural and conditional knowledge in a systematic and sequential fashion to first provide definitions of the processes of mitosis and meiosis . Using probing questions and incentives to gain some insight into her students' conception she remarked: "There is an extra mark for mentioning the number of chromosomes and no one got that..what can you say about the number of chromosomes in mitosis?". In the course of the lesson the definitions were followed by the justification for the two processes: "the purpose of mitosis is to produce cells which are identical to the parent cell for growth and replacement of worn out cells and meiosis is for the production of gametes". Having established why mitosis and meiosis are important she followed it up by closed type diagnostic questioning: "which part of the body does mitosis occur? Which cells in our body undergo mitosis?" Later a step-wise description of the stages of mitosis and meiosis using pictorial diagrams to illustrate how the two processes function and differ. Likewise Leon and Lillian first described and explained why mitosis and meiosis are important to the organism but Leon omitted talking about how the processes of cell division occur. He explained "mitosis is the process involved in cell growth". ... and meiosis is the "process responsible for the production of gametes with haploid nuclei (a cell containing half the number of chromosomes), which fuse during fertilization to form one diploid cell (a cell containing the full number of chromosomes), called the zygote". Lillian also demonstrated her content knowledge, notably her procedural and conditional content knowledge in describing mitosis and meiosis formation and explaining why the processes were considered important in cell growth:"It (mitosis) also occurs in the stem which results in the enlargement of the width of the stem and in the fruit which results in enlargement of the fruit".

In summary all four teachers demonstrated the necessary and sufficient content knowledge in their respective PCK, which comprised of declarative, procedural and conditional content knowledge in the teaching of school genetics. They were invariably integrated with the strategies they used for teaching.

\section{Teachers' knowledge of topic-specific instructional strategies}

During the pre-lesson interviews, Lucy, Lily Lillian and Leon indicated that they would use familiar examples, contexts and analogies of common materials to introduce their lessons. The intention was to provide their students with relevant, authentic situations in the form of familiar contexts, relatable to specific genetics concepts and ideas. The use of familiar contexts was meant to "arouse interest" and stimulate focused students' thinking. All four teachers mentioned that they would use illustrations such as pictorial diagrams, clearly labelled diagrams on the chalk board to explain the functions and relationships between genetics concepts of chromosome, gene and allele because "this is an area that students find particularly difficult to understand". Lily and Lillian emphasized the importance of illustrations to help students "visualize processes" so as to be able abstract ("take from') meaning 
from the defined genetics concepts. According to Lillian, her past teaching experience showed that without the use of visual aids, it was difficult for students to comprehend genetics terms, including biological processes.

Concerning the lessons observed, on the topic of Inheritance, although the four teachers adopted different instructional approaches they all began their lessons by using the questioning technique to try to link previously taught concept (familiar content and context) to the new topic to be taught. Discussions about characteristic features inherited in a family say, that are passed down from generation to generation such as skin complexion, height, eye colour, as well as DNA testing to determine paternity were used to introduce the lessons to enhance their relevance and to engender motivation. There was a blend of content and pedagogy in teaching the topic. Lillian started by first finding out her students' ideas about the term 'inheritance'; and later followed through with probing questionings about what they thought was responsible for those characteristic features of resemblances in the family. Lucy's use of the same oral questioning techniques which sometimes required of the students the application of higher order thinking skills was to assess what students know- before, during and after the lessons: "Can you tell me what is there in the sperm or ovum that has resulted in you being the person you are? What do you think really brought up this creature that is you?" According to Lucy her oral questioning techniques were primarily aimed at "assessing students ' prior knowledge and students' comprehension of what was taught".

Lucy in addition to her questioning techniques used what might be construed as an advance organizer in her teaching approach. This instructional strategy was unique to her and clearly different from all the other participating teachers. Prior to teaching the genetics lesson in class, part of Lucy's instructional strategy was to ask students to read the relevant chapter in their textbook the previous day as homework assignment and to produce physical models based on their understanding of the topic. Her approach was designed to facilitate orientation to new information or unknown information. During the lessons students were called out individually, to try present the concepts to the class (peer teaching) using the physical models they produced as teaching aid. Lucy explained that peer teaching should provide her with some indication of potential "areas or sources of difficulty and any conceptual misunderstandings", which would then be incorporated into the lesson for possible remediation. This approach was exactly what was observed in her lessons.

Lily and Leon likewise used contexts that were familiar to students to introduce their lessons so as to "engender interest and relevance". For instance Leon used several examples of human traits that are controlled by alternative forms of the same gene, known as alleles, (e.g. tongue rolling and folding of arms-which the class demonstrated) to demonstrate the concept of allele to his students. Lily used, an analogy of a recipe book (as a chromosome) to explain the relationship and differences between a chromosome and a gene (recipe). The DNA in the chromosome was described as a "coded recipe for making proteins and each chromosome contains many recipes (or genes)." Both teachers frequently used in the lessons observed pictorial charts, and carefully labelled diagrams on the chalkboard to illustrate factual information about homologous chromosomes for example, and to assist students to visualise the more abstract concepts and to comprehend the relationships between concepts of chromosome, gene, and allele. Leon's omission of the stages of the processes of cell division was consistent with what he said in the pre-lesson interviews that he did not plan to teach the stages because the syllabus says they are not required. Leon's reason was that, it is the syllabus which gives me the guide as to which topics to teach and also it states some of the objectives that have to be achieved when teaching this topic. That is my primary source of information of what is to be taught. Throughout the years I have used various textbooks which I have compiled into notes"

But Leon's interpretation of the syllabus about stages of meiosis for example could prove a little problematic, because it would be difficult for students to handle other genetics concepts later demanded by the syllabus such as solving Mendelian genetic problems which require the calculation and prediction of the results of monohybrid crosses involving ratios. 
Other instructional strategies employed by all the teachers included written classwork, oral questioning and homework assignments to assess how well learners had understood the lessons taught. In the post-teaching questionnaire in which they were asked to justify their teaching approaches, Lily indicated that since her "students had difficulty in answering some questions on chromosomes and genes, prior to the lesson on mitosis I gave them the relevant chapter on genes in the biology textbook to read as homework and to answer questions at the end of the chapter". Leon, on the other hand used mostly oral questioning of closed-type questions focusing on definitions during teaching to elicit students' understanding of the concepts being taught because "they are quicker and and easier to use regarding the available time". Lily and Lilian confirmed what they had said before about using pictorial diagrams, namely, that "Genes and chromosomes are too abstract and learners need teaching aids to be able to visualize them".

There were similarities and differences in the teachers' PCK profile with regard to the instructional strategies. They individually employed various topic-specific instructional strategies that included the use of advance organizer, peer teaching, familiar contexts and analogies, illustrative diagrams and questioning techniques, and sequencing of content to teach the genetics concepts. There was no evidence however of the four teachers' knowledge of students preconceptions, prior to teaching. It was also noted that none of the teachers used any of the structured learning activities such as practical investigations, individual or group student experiments, or simulations to assist learners in visualising or internalising genetics concepts and processes. None of these activities were found in the students' workbooks.

\section{Teachers' knowledge of students' preconceptions and learning difficulties}

In the descriptions of their lesson plans, there was no indication or evidence that the four teachers had fore-knowledge of, or had taken into account in planning their lessons their students' preconceptions to be used perhaps as teaching points on the students' behalf. For instance there were no pre-or postactivities in the lesson plan or the lessons observed designed to identify, remediate or eliminate any preconceptions or potential learning difficulties which students might have experienced during the lessons as a result of misconceptions. Furthermore all the teachers' responses to the questionnaire on whether they had knowledge of their genetics-related preconceptions showed that they had not much knowledge of their students' preconceptions about the topic of genetics. They however, stated that they would use the questioning technique to probe their students' existing knowledge about geneticsrelated "concepts previously taught".

.

Concerning the teachers' knowledge of their students' potential learning difficulties, in planning their lessons, all four teachers mentioned difficulties that had to do with the terminology of genetics and comprehending the processes of cell division. They were unanimous in stating that students had difficulty in differentiating between the genetics terms 'chromosomes' and, 'genes', 'genes' and 'alleles', mitosis and meiosis and sometimes used those paired terms interchangeably. Lucy said "students scarcely distinguish between homologous chromosomes and chromatids"., Three of the teachers Lucy, Lillian and Lily wrote that students struggle with grasping "how chromatids separate during cell division and the reduction of chromosome number during meiosis". The lesson observations confirmed that Lucy's and Lilian's students had the problems they had earlier on identified. In the lessons observed in mitosis Leon did not always use appropriate questioning or diagnostic assessment techniques to probe students' learning in order to obtain useful feedback. In his journal self-reflections he recognized this shortcoming and specifically wrote that "the next time I teach the same concepts...I will always immediately assess their (his students) understanding of the concepts in class through better questioning... so as to obtain student feedback" that could be used to improve his teaching.

Most of the students' learning difficulties according to the teachers were discovered through students' written classroom and homework assignments, oral questioning and peer teaching. In short through 
their classroom teaching experiences. In addition the teachers also thought that the sources of difficulty could be attributable to the "abstract nature of some of the genetics concepts because some of these are not readily visible and students just learn the definition without understanding their meaning. Language can be a problem too". Lily and Lucy addressed students' difficulties by discussing these on a one-on-one basis while monitoring individual classwork or during whole class discussion during the lessons. Lillian most of the time used well illustrated diagrams using coloured chalks for differentiating concepts and to address difficulties related to the relationships among the various concepts of gene, chromosomes and alleles. The three teachers encouraged discussion and justification of the ideas that learners might bring during the genetics lessons.

Leon did not respond to the relevant questionnaire section and indeed there was no evidence of him having addressed students' difficulties during the lessons observed.

\section{Summary of the teachers' PCK profiles}

In summary, given the assumption that successful teachers have what might be termed adequate or 'rich' PCK it would be valuable to reflect on the four teachers' PCK outcomes and perhaps to speculate on what aspects or characteristics are crucial for PCK to be named rich. Lucy's PCK profile in genetics teaching, in terms of the three knowledge bases may be characterized as consisting of declarative, procedural and conditional content knowledge in the instructional use of familiar or authentic contexts and analogies to establish relevance and meaning as far as her students' learning was concerned. To the extent that those knowledge domains constituted PCK outcomes, Lily, Leon and Lillian's PCK profiles could be said to be similar to Lucy's. Even though all four teachers used the same content sequence in presenting the school genetics topic on Inheritance, Lucy's demonstrated pedagogical knowledge involved the use of advance organizer in the form of peer teaching, to try to make the concepts meaningful to her students and for eliciting students' difficulties or conceptual misunderstanding.. The use of familiar daily life examples, well labelled diagrams constituted specific strategies that Lily and Lilian used to teach genetics concepts so as to make the more abstract genetics concepts more intuitable to their students. Leon however demonstrated mainly declarative and conditional content knowledge in his teaching of the topic on meiosis and mitosis and did not particularly address his students learning difficulties. His instructional strategies in the use of daily life examples, well-labelled diagrams on the chalkboard, like his other counterparts, and complemented by his compiled notes over the years, were designed to help students to grasp the definitions of the more abstract genetics concepts. Perhaps the question could be asked as to how Leon was able to consistently obtain good biology results in the public exam. It is possible that the other aspects of his PCK were sufficiently well integrated and adequate to address the cognitive demands of the overall senior certificate biology syllabus. Genetics topics constitute only a certain minimum percentage of the overall examined biology syllabus. PCK is assumed to be topic specific and not a generic term for the whole biology syllabus topics. The four teachers however used varied topic-specific instructional strategies as a component of their presumed PCK.

\section{How did the teachers develop their PCK in genetics teaching?}

The post-lesson teacher interviews together with the analysis of teacher journals were meant to ascertain how the participating teachers might have developed their PCK in school genetics teaching. The disciplinary courses taken at the university were regarded by the teachers themselves as the major source of their PCK development. Lily, like her other colleagues, reported that she acquired her genetics content knowledge from her university degree content courses, and knowledge about teaching methods and strategies from her postgraduate teaching methods courses. The genetics content knowledge learned during their formal education was significantly at a higher level than what they were expected to teach at school. In consequence, part of the development of their teacher 
knowledge base was basically on how "to transform their content knowledge for classroom use in forms that would make it accessible to their students".

The three teachers (Lucy, Lily and Leon) with over ten years of classroom teaching experience indicated that improvement in their instructional knowledge and skills had been aided particularly by the use of biology textbooks and curriculum materials and publication guidelines and teaching experience. Lucy concluded that her teaching had changed from being predominantly "teachercentred involving teacher 'chalk and talk' when I started to being more student-centred". Such teacher change in teaching genetics has helped to improve her "students' performance in external examinations... and this performance has improved over the years compared to when I started". Lillian, with the least number of years of teaching experience, attributed her improving abilities and increasing confidence to "peer support" (institutional support) from her "more experienced departmental colleagues".

In-service professional development biology workshops were identified as one of the factors that contributed to the teachers' PCK development. For example "skills for representing genetics subject matter"...and "skills to distinguish between effective and ineffective representations... the strengths and weaknesses of various representations" and other activities that support learning were taught at various teacher-support workshops according to Leon, Lucy and Lily.

Further, analysis of their journal entries and questionnaire responses, revealed that all four claimed to have further developed, or refined their pedagogical content knowledge as a result of the post lesson reflections guideline included in the teacher journal. For instance Lucy indicated that the next time she taught the same genetics concepts she would "explain cell division in more detail and use group or teacher demonstration or simulation experiments to help my students to visualize and better understand the processes" Lily reflected that she would use "the strategy of students' reading the topic before hand" to provide them with minimum "background knowledge". Leon and Lilian had similar resolutions about improving on their student assessment and teaching strategy respectively. The outcome of their reflective practices would tend to confirm the suggestion that given the enabling environment PCK is not a stagnant entity (Miller, 2007), but is liable to change.

\section{Discussion}

This discussion is presented in accord with this study's main research questions of what PCK as defined, the participating biology teachers have in school genetics teaching and how they developed it. We utilized PCK as a theoretical framework in order to identify and analyse the teachers' knowledge base in the context of teaching school genetics. All four teachers used mostly declarative content knowledge to teach the definitions and explain the genetics concepts of chromosomes, genes and alleles. These concepts are known to be problematic and students find them hard to grasp and distinguish (Chu \& Reid, 2012). Predominant use of declarative knowledge was supposedly influenced by the biology syllabus, which required students to know only definitions of these concepts. With regard to the teaching of biological processes such as mitosis and meiosis, three of the four teachers used predominantly their procedural and conditional content knowledge to make the stages accessible to their students, and to explain why these processes were important in an organism. The decision to deploy declarative and/or procedural content knowledge (and allowing for heterogeneity too), was probably determined by the nature of the topics to be taught. In mitosis and meiosis, the syllabus does not require students to know the details of the stages of the processes. Lack of detail about what is expected of the teacher in teaching those processes appeared to constrain one of the teachers, Leon, to teach according to his interpretation of the syllabus. Leon did not go beyond the recommendations of the syllabus implying perhaps somewhat of a limited PCK outcome in school 
genetics concept teaching. It would be unfair however, to conclude that Leon did not know the stages of those two processes simply because his interpretation of the syllabus guidelines said not to cover it. Clearly, this is an instance where the context in this case an existing curriculum document could be restrictive or facilitative in the development or otherwise of adequate or rich PCK; just as a lack of the availability of resources in a school could impact on the teacher's PCK as in the case of Lillian. The results of this study indeed showed that the curriculum document was one of the most influential determinants of the participating teachers' PCK and served both as knowledge source and knowledge organizer in planning and sequencing the content of their teaching.

In this study, all four teachers introduced their genetics concepts using familiar contexts and analogies followed by a review of previously taught concepts of cell structure and fertilization to locate the hereditary structures of chromosomes and genes. This was followed by explanations of the relationship between genetics concepts coupled with illustrative and well-labelled diagrams designed to help students visualize and internalise some of the not too readily intuitable or imageable genetics concepts. The teachers' approach of beginning their teaching by drawing students' attention to observable features of inherited human characteristics before gradually shifting and linking those to the more intangible and abstract aspects of sub-microscopic processes and concepts is in accordance with the views of Knippels, Waarlo and Boersma (2005). With regard to pedagogical knowledge, Knippels et al. (2005) suggested that activities designed to teach students about biological inheritance should begin in areas that are familiar and easily understandable for students. This is not to suggest that there is only one way or instructional approach of teaching the topic even though the authors suggested a sequence of activities to achieve those ends.

Pertaining to the teaching of the processes of cell division in particular, Williams, DeBarger, Montgomery, Zhou and Tate (2012) suggested that the teaching of these processes should also follow a sequence for improved performance: first, should be the presentation of the broader purpose of mitosis and meiosis, in terms of cell growth and replacement of damaged cells and genetic diversity, respectively. According to them, this starting point is likely to help establish a context that enables students to effectively learn about these topics. Again that is not to say that there is only one way in which to approach the teaching of mitosis and meiosis. Lucy and Lily who began by teaching the significance of mitosis and meiosis before describing their stages could be said to have followed the sequence proposed by integrating those two constructs -knowledge of content including the how and why (conditional knowledge) and pedagogical knowledge for effective learning. Lillian however, began by describing the stages of the processes using her procedural knowledge before highlighting their importance as evidenced in her use of conditional knowledge. Leon's approach was quite different from the others in the sense that he left out the stages of mitosis and meiosis and focused more on the declarative and conditional content knowledge of his teaching. The similarities and differences in the teachers' content and pedagogical knowledge components of their 'PCK teaching profiles are quite evident in terms of the sequencing, the content taught and the instructional strategy.

Individual or group experimental activities and teacher-prepared models were however absent from all the four teachers' lesson plans and the lessons observed. The lack of structured practical and experimental work could partly be attributable to lack of laboratory resources and facilities and partly as a result of "lack of time"

All four teachers demonstrated insufficient knowledge of students' preconceptions in school genetics. The reasons for this lack of knowledge were not always clear. It has to be said however that this type of knowledge of students' preconceptions is tacit and it is possible that they might not have been aware themselves that it influenced their choice of sequence and teaching approaches. It is also possible that some of the teachers' oral assessment techniques might have contributed to this deficit in teacher knowledge of students. The oral questions were mostly not intended to be diagnostic or 
formulated in ways designed to gain some insight into students' existing conceptions. Also in Swaziland, practising teachers as a matter of course do not use any teaching portfolios, or journals to record personal reflections of lessons taught. Current research however, indicates that the ability to think reflectively is not only crucial for teachers' success in the classroom but also as a lifelong skill (Dreschler \& Van Driel, 2008). It could therefore be argued that teachers who lack the skill and practice of reflective thought are at a disadvantage in developing 'rich PCK'.

Given that the participating successful teachers clearly demonstrated two knowledge domains, could the two: knowledge of content and pedagogical knowledge be construed as adequate or rich PCK in the context of school genetics teaching? This is an empirical question that would require an assessment or evaluation of student performance on the basis of such intervention or treatment. Specifically, more-evidence based studies are needed in teacher knowledge base or PCK research on what counts as content-specific "rich PCK" that can enhance student understanding and achievement.

Lucy, who may be regarded as having an adequate or relatively rich PCK, used a variety of instructional strategies including peer teaching to make the concepts accessible to her students. In her case, student-constructed physical models and analogies served to elicit any conceptual misunderstandings including preconceptions which were used as teaching points in introducing the topics. Such an approach was likely to facilitate students' comprehension by the teacher focusing on how best to link new knowledge to existing alternative frameworks.

\section{Conclusion}

In conclusion, this study has been an attempt to explore four participating teachers' PCK in genetics teaching and its development. As a theoretical framework PCK was utilized to analyse the amalgam of three categories of knowledge, the experienced biology teachers draw on in teaching school genetics. Some of the limitations of this study include lack of evidence about the effectiveness of the individual teachers' PCK profiles on student genetics learning and achievement.

The methods used were a direct implication of the study's theoretical framework since in-depth and rich description data were needed to extract information about participating teachers' constructed PCK outcomes in school genetics teaching. The similarities and differences in the PCK profiles of the four teachers were highlighted and the findings have led to the conclusion that PCK is a complex form of teacher knowledge constructed by teachers themselves to convey their understanding of specific subject matter content knowledge using idiosyncratic multiple strategies to enhance student learning. As to what constitutes 'rich PCK' we posit that it is an empirical question requiring more evidencebased studies in teacher education research on what should count as 'rich PCK' in teacher knowledge construction.

The educational implications of the findings of this study suggest that teacher reflective thinking skills be included as an outcome of any teacher education programme and which should be assessed. Further, teacher education programmes in Swaziland should document lists of student misconceptions and alternative frameworks of science concepts that are generally considered difficult to learn as a way of enriching pre-and in-service science teachers' PCK.

\section{References}

Abell, S. K. (2007). Research on science teacher knowledge. In S. K. Abell \& N. G. Lederman (eds.), Handbook of research on science education (pp. 1105-1149). Mahwah, NJ: Lawrence Erlbaum.

Appleton, K. (2006). Science pedagogical content knowledge and elementary school teachers. In Ken Appleton (ed.). Elementary science teacher education: international perspectives on contemporary issues and practice. London: Lawrence Erlbaum. 
Arzi, H. J. \& White, R. T. (2008). Change in teachers' knowledge of subject matter: a 17-year longitudinal study. Science Education 92, 221-251. Doi:10.1002/sce.20239.

Barmby, P., Kind, P. M. \& Jones, K. (2008). Examining changing attitudes in secondary school science. International Journal of Science Education, 30(8), 1075-1093.

Brown, P., Friedrichsen, P. \& Abell S. (2013). The development of prospective secondary biology teachers PCK. Journal of Science Teacher Education, 24, 133-155. Doi:10.1007/s10972-012-9312-1

Carlsen, W. S. (2001). Domains of teacher knowledge. In J. Gess-Newsome \& N. G. Lederman (eds.), Examining pedagogical content knowledge (pp. 133-144). Dordrecht, Netherlands: Kluwer Academic.

Chu, Y.-C. \& Reid, N. (2012). Genetics at school level: addressing the difficulties. Research in Science \& Technological Education, 30(3), 285-309, Doi: 10.1080/02635143.2012.732059

Cochran, K. F., De Ruiter, J. A. \& King, R. A. (1993). Pedagogical content knowing: an integrative model for teacher preparation. Journal of Teacher Education, 44, 263-272.

De Jong, O., Veal, W. R., \& Van Driel, J. H. (2002). Exploring chemistry teachers' knowledge base. In J. K. Gilbert, O. De Jong, R. Justi, D. F. Treagust \& J. H. Van Driel (eds.), Chemical education: towards research-based practice (pp. 369-390). Dordrecht, Netherlands: Kluwer Academic.

De Jong, O. (2010). Exploring science teachers' pedagogical content knowledge. In D. Psillos, P. Kariotoglou, V. Tselfes, E. Hatzikraniotis, G. Fassoulopoulos \& M. Kallery (eds.), Science education research in the knowledge-based society (pp. 373-381). Dordrecht, Netherlands: Kluwer Academic.

Drechsler, M. \& Van Driel, J. (2008). Experienced teachers' pedagogical content knowledge of teaching acid-base chemistry. Research in Science Education, 38, 611-631. DOI: 10.1007/s11165007-9066-5.

Ekis, H. (2012). Review of studies related to PCK in the context of science teacher education: Turkish case by Halil Ekis. Educational Sciences: Theory \& Practice, 12(1), 497-505.

Examinations Council of Swaziland (ECOS). (2007-2012). Summary results report per syllabus/centre-IGCSE/SGCSE Biology. Mbabane: Examination Council of Swaziland. Available from: $\quad$ http://www.examscouncil.org.sz/Shared\%20Documents/Statistics/Subject\%20Stats/O... (Accessed 16/03/2010 and 28/08/2013)

Examinations Council of Swaziland (ECOS). (2009). Swaziland General Certificate of Secondary Education Biology Syllabus examinable 2011-2012. Mbabane: Examination Council of Swaziland.

Examinations Council of Swaziland (ECOS). (2008, 2009, 2012). International General Certificate of Secondary Education: Biology examination report. Mbabane: Examination Council of Swaziland.

Gess-Newsome, J. (2001). Pedagogical content knowledge: An introduction and orientation. In J. Gess-Newsome \& N. G. Lederman (Eds.), Examining pedagogical content knowledge (pp. 3-20). Dordrecht: Kluwer Academic Publishers.

Greene, B. A., Lubin, I. A., Slater, J. L., \& Walden, S. E. (2013). Mapping changes in science teachers' content knowledge: concept maps and authentic professional development. International Journal of Science and Technology, 22, 287-299. Doi: 10.1007/s10956-012-9393-9

Henze, I., Van Driel, J. H. \& Verloop, N. (2008). Development of experienced science teachers' pedagogical content knowledge of models of the solar system and the universe. International Journal of Science Education, 30(10), 1321-1342.

Ijeh, B. S. (2012). How competent mathematics teachers develop pedagogical content knowledge in statistics teaching. Unpublished doctoral dissertation: University of Pretoria, South Africa.

Ijeh, B. S., \& Onwu, G.O.M. (2013). What instructional skills and strategies do competent mathematics teachers use in teaching statistics in school mathematics during PCK development. International Journal of Education Science, 5(4), 363-374.

Juttner, M., Boone, W., Park, S. \& Neuhaus, B. J. (2013). Development and use of a test instrument to measure biology teachers' content knowledge (CK) and pedagogical content knowledge (PCK). Education, Assessment, Evaluation and Accountability, 25(1), 45-67. Doi: 10.1007/s11092-013-9157y

Juttner, M., \& Neuhaus, B. J. (2012). Development of items for a pedagogical content knowledge test based on empirical analysis of pupils' errors. International Journal of Science Education, 34(7), 1125-1143, Doi: 10.1080/09500693.2011.606511 
Kapyla, M., Heikkinen, J. \& Asunta, T. (2009). Influence of content knowledge on pedagogical content knowledge: the case of teaching photosynthesis and plant growth. International Journal of Science Education, 31(10), 1395-1415.

Kaya, O. N. (2008). A student-centred approach: assessing the changes in prospective science teachers' conceptual understanding by concept mapping in a general chemistry laboratory. Research in Science Education, 38, 91-110.

Kaya, O. N. (2009). The nature of relationships among the components of pedagogical content knowledge of pre-service science teachers: 'ozone layer depletion' as an example. International Journal of Science Education, 31(7), 961-988.

Kazeni, M. \& Onwu, G. (2013). Comparative effectiveness of context-based and traditional approaches in teaching genetics: student views and achievement. Africa Journal of Research in Mathematics, Science and Technology Education, 17(1-2), 50-62, Doi: 10.1080/10288457.2013.826970

Kind, V. (2009). Pedagogical content knowledge in science education: perspectives and potential for progress. Studies in Science Education, 45(2), 169-204.

Knippels, M. C. P. J., Waarlo, A. J., \& Boersma, K. T. (2005). Design criteria for learning and teaching genetics. Journal of Biological Education, 39(3), 108-112.

Lee, E., \& Luft, J. A. (2008). Experienced secondary science teachers' representation of pedagogical content knowledge. International Journal of Science education, 30(10), 1343-1363, DOI: 10.1080/09500690802187058

Loughran, J., Berry, A. \& Mulhall, P. (2012). Understanding and developing science teachers' pedagogical content knowledge, $2^{\text {nd }}$ edition. Netherlands: Sense Publishers.

Magnusson, S., Krajcik, H. \& Borko, H. (2001). Nature, sources and development of PCK. In J. GessNewsome \& N.G. Lederman (Eds.). Examining PCK (pp. 95-132). Dordrecht: Kluwer Academic.

Marope, M. (2010). The education system in Swaziland: training and skills development for shared growth and competitiveness. Washington, DC: World Bank.

McConnell, T. J., Parker, J. M., \& Eberhardt, J. (2013). Assessing teachers' science content knowledge: a strategy for assessing depth of understanding. Journal of science Teacher Education, 24, 717-743. Doi: 10.1007/s10972-013-9342-3

Merriam, S. B. (2009). Qualitative research: a guide to design and implementation. Revised and expanded from qualitative research and case study applications in education. USA: Jossey-Bass.

Miller, M. L. (2007). Pedagogical content knowledge. In G. M. Bodner \& M. Orgill, Theoretical frameworks for research in chemistry/science education. London: Pearson Education.

Morrison, J. A. \& Lederman, N. G. (2003). Science teachers' diagnosis and understanding of students' preconceptions. Science Education, 87, 849-867. Doi: 10.1002/sce.10092.

Park, S. \& Chen J. (2012). Mapping out the integration of the components of pedagogical content knowledge (PCK): examples from high school biology classrooms. Journal of Research in Science Teaching, 49(7), 922-941.Doi:10:1002/tea.21022

Park, S., \& Oliver, J. S. (2008). Revisiting the conceptualization of pedagogical content knowledge (PCK): PCK as a conceptual tool to understand teachers as professionals. Research in Science Education, 38, 261-284.

Penso. S. (2002). Pedagogical content knowledge: how do student teachers identify and describe the causes of their pupils' learning difficulties? Asia-Pacific Journal of Teacher Education, 30(1), 25-37. Doi: 10.1080/13598660120114959.

Rollnick, M., Bennett, J., Rhemtula, M., Dharsey, N., \& Ndlovu, T. (2008). The place of subject matter knowledge in pedagogical content knowledge: a case study of South African teachers teaching the amount of substance and chemical equilibrium. International Journal of Science Education, 30(10), 1365-1387.

Schmelzing, S., Van Driel, J. H., Juttner, M., Brandenbusch, S., Sandmann, A. \& Neuhaus, B. J. (2013). Development, evaluation, and validation of a paper-and-pencil test for measuring two components of biology teachers' pedagogical content knowledge concerning "cardiovascular system". International Journal of Science and Mathematics Education, Doi: 10.1007/s10763-012-9384-6. 
Shulman, L. S. (1986). Those who understand: knowledge growth in teaching. Educational Researcher, 15(2), 4-14. Available from: http://www.jstor.org/stable/1175860, (Accessed 22/09/2010).

Van Driel, J. H., Beijaard, D., \& Verloop, N. (2001). Professional development and reform in science education: the role of teachers' practical knolwedge. Journal of Research in Science Teaching, 38(2), 137-158

Van Driel, J.H., De Jong, O., \& Verloop, N. (2002). The development of preservice chemistry teachers' PCK. Science Education, 86, 572-590.

Williams, M., DeBarger, A. H., Montgomery, B. L., Zhou, X. \& Tate, E. (2012). Exploring middle school students' conceptions of the relationship between genetic inheritance and cell division. Science Education, 96(1), 78-103. Doi: 10.1002/sce.20465. 


\section{Appendix I: An example of lesson observation analysis}

Using her usual peer teaching method, Lucy the teacher (T) offered students (SS) a chance to present what they read about the concept of meiosis before she taught it.

Line 1: S1 - 'Teacher I struggled to understand meiosis, especially the part about how the number of chromosomes end up being half because it is like the same process as mitosis occurs.'

Line 2: T- May you start by describing mitosis then so that we see where you fail to make the difference when you talk about meiosis.

Line 3: S1 - 'In the first stage of meiosis (Referring to a diagram he drew on the chalkboard from his textbook) homologous chromosomes are close together, two long ones and two short ones. They pair up. The second stage, homologous chromosomes split, centrioles move to the poles and spindles pull the chromosomes apart. Then there is like the haploid number of chromosomes. How is it half as it happens the same way as in mitosis?'

Line 4: S1 continued and asked the class - 'Am I correct? Do the resulting cells contain a haploid number of chromosomes?'

Line 5: SS gave chorus responses: 'Yes' and 'No.' without any reasons.

Line 6: T- I think when you all have struggled a bit it would be much easier to understand when I explain.

Line 7: T - In the first place why do we need meiosis?... Why do we need another type of cell division different from mitosis?... I am asking what is the significance of meiosis?

Line 8: S2 - Answered by reading from his textbook: 'Meiosis results in the formation of gametes. It is necessary that we have the haploid number of chromosomes because the gametes form the zygote. If the gametes had the full number of chromosomes, each time a zygote was formed it would have double the number of chromosomes. And that will continue doubling. "

Line 9: T - Yes, (teacher accepts the explanation and goes on to say), Meiosis is the type of cell division specifically for the formation of gametes and therefore in meiosis the daughter cells should have half the number of chromosomes.

Line 10: T - Let us now follow the stages (pointing to the diagram on the chalkboard of the stages of meiosis without including the scientific names of the different stages) to see what happens in meiosis that results in half the number of chromosomes. Is that okay?

Line 11: SS - 'Yes'.

Line 12: T - In meiosis we are forming the gametes, the sex cells. Our daughter cells shouldn't contain the same number of chromosomes as the parent cell as the learner explained. The chromosomes should be half. That is why sometime meiosis is referred to as the reduction division. Why reduction division? Because the number of chromosomes in the nucleus is reduced. We refer to such a nucleus as a haploid nucleus because it contains half the number of chromosomes as compared to the initial nucleus.

Line 13: T - Lucy used coloured chalk to illustrate replication and separation of homologous chromosomes during meiosis. She used a hypothetical cell with two chromosomes in the nucleus.

Line 14: T - So initially we have two chromosomes represented by one white chalk and one purple chalk. Before cell division, each chromosome replicates and now we have two white and two purple. Each pair of chromosomes (pair of white and pair of purple chalk) is known as sister chromatids.

Line 15: T - Why replicate? Because the chromosome has to make a copy of itself so that one copy can go to each new cell. When the cell first divides in meiosis the sister chromatids will not separate (referring to a diagram she drew on the chalkboard) but the chromosomes do.

Line 16: T - Do you understand S1? Pointing to the student who had difficulty in describing meiosis

Line 17: S1- 'Yes'. 
The teacher used her instructional strategy of asking the students to first read the relevant chapter and later individually present to the class in the form of peer teaching. Her strategy allowed her to identify a student's difficulty (knowledge of student learning difficulty) in comprehending the process of meiosis (Line 1). She used questioning technique (pedagogical knowledge) to probe students' understanding of the purpose or significance of meiosis (Line 7). Even though the student responded by reading from the textbook she further explained to the class by first getting them to understand the 'why' of the process of meiosis, followed by the description of the stages (procedural knowledge), definition of meiosis (declarative knowledge) thus demonstrating her content knowledge of conditional (Lines 9, 12), procedural (Lines 10, 14 and 15) and declarative (Line 9) knowledge. 